\title{
Evaluation of three immunochromatographic tests for rapid detection of antibodies against SARS-CoV-2
}

\author{
Gladys Virginia Guedez-López ${ }^{1} \cdot$ Marina Alguacil-Guillén ${ }^{1}$ (1) • Patricia González-Donapetry ${ }^{1} \cdot$ Ivan Bloise ${ }^{1}$. \\ Carolina Tornero-Marin $^{2}$ - Juan González-García ${ }^{3}$ - Jesus Mingorance ${ }^{1}$ - Julio García-Rodríguez ${ }^{1}$ - on behalf of the \\ SARS-CoV-2 Working Group
}

Received: 9 June 2020 / Accepted: 11 August 2020 / Published online: 17 August 2020

(C) Springer-Verlag GmbH Germany, part of Springer Nature 2020

\begin{abstract}
Lateral flow immunoassays (LFIA) for rapid detection of specific antibodies (IgM and IgG) against SARS-CoV-2 in different human specimens have been developed in response to the pandemic. The aim of this study is to evaluate three immunocromathographic assays (Sienna ${ }^{\circledR}$, Wondfo ${ }^{\circledR}$ and Prometheus ${ }^{\circledR}$ ) for detection of antibodies against SARS-CoV-2 in serum samples, considering RT-qPCR as a reference. A total of 145 serum samples from 145 patients with clinical suspicion of COVID-19 were collected: all of the samples were tested with Sienna ${ }, 117$ with Wondfo $\AA$ and 89 with Prometheus $®$. The overall results of sensitivity, specificity, positive predictive value and negative predictive value obtained were as follows: $64.4 \%, 75 \%, 85.5 \%$ and $47.8 \%$ with Sienna ${ }^{\circledR} ; 45.2 \%, 81.8 \%$, $80.5 \%$ and $47.4 \%$ with Wondfo $®$ and $75.5 \%, 12.5 \%, 51.4 \%$ and $29.4 \%$ with Prometheus $®$. The accuracy of the test for Sienna ${ }^{\circledR}$, Wondfo ${ }^{\circledR}$ and Prometheus ${ }^{\circledR}$ was $67.6 \%, 59 \%$ and $47.2 \%$, with a prevalence of COVID-19 of $69.7 \%$, $62.4 \%$ and $55.1 \%$ respectively. Sensitivity of the three tests (Sienna ${ }^{\circledR}$, Wondfo ${ }^{\circledR}$ and Prometheus ${ }^{\circledR}$ respectively) along the three different stages was $36.6 \%, 18.8 \%$ and $68.6 \%$ in the early stage (first week); $81.3 \%, 74.1 \%$ and $90.9 \%$ in the intermediate stage (second week) and $100 \%, 83.3 \%$ and $100 \%$ in the late stage (third week). The results demonstrate that even though Prometheus ${ }^{\circledR}$ presented a high sensitivity, the specificity was notably lower than the other two tests. Sienna ${ }^{\circledR}$ showed the greatest contrast between sensitivity and specificity, achieving the best accuracy, followed by Wondfo®. The sensitivity of the three ICT assays was higher in late stages of the disease.
\end{abstract}

Keywords SARS-CoV-2 $\cdot$ COVID-19 $\cdot$ Serology $\cdot$ Lateral flow immunoassays $\cdot$ Immunochromatographic strip assay

Gladys Virginia Guedez-López and Marina Alguacil-Guillén contributed equally to this work.

Electronic supplementary material The online version of this article (https://doi.org/10.1007/s10096-020-04010-7) contains supplementary material, which is available to authorized users.

Marina Alguacil-Guillén

marinalguacil11@gmail.com

1 Clinical Microbiology Department, Hospital Universitario La Paz, Paseo de La Castellana 261, 28046 Madrid, Spain

2 Rheumatology Department, Hospital Universitario La Paz, Madrid, Spain

3 Internal Medicine Department, Hospital Universitario La Paz, Madrid, Spain

\section{Introduction}

In late December 2019, a novel coronavirus was identified as the etiological agent of anew pneumonia [1,2]. The etiological agent, named as SARS-CoV-2, rapidly spread to other cities in China and to other countries worldwide and on 11 March World Health Organization (WHO) declared the outbreak as a pandemic. This situation has forced many countries to adopt firm measures in order to promote early detection of COVID-19 and early isolation of the cases, track contacts and encourage distancing measures.

Real-time reverse transcription quantitative polymerase chain reaction (RT-qPCR) has been established as the gold standard for microbiological diagnostic of SARS-CoV-2 infection, targeting at least two different regions of SARS-Cov2 genome in order to avoid cross-reactivity with other coronavirus and the potential genetic drift of SARS-CoV-2 [3-6]. 
Table 1 Demographic and clinical characteristics of patients included in the study

\begin{tabular}{|c|c|c|c|c|c|}
\hline \multirow[b]{2}{*}{ Characteristics } & \multicolumn{3}{|c|}{ Healthcare workers } & \multicolumn{2}{|c|}{$\begin{array}{l}\text { Patients admitted to the Emergency } \\
\text { Department }\end{array}$} \\
\hline & $\begin{array}{l}\text { Sienna® } \\
(n=95)\end{array}$ & $\begin{array}{l}\text { Wondfo® } \\
(n=95)\end{array}$ & $\begin{array}{l}\text { Prometheus }{ }^{\circledR} \\
(n=89)\end{array}$ & $\begin{array}{l}\text { Sienna }{ }^{\circledR} \\
(n=50)\end{array}$ & $\begin{array}{l}\text { Wondfo® } \\
(n=22)\end{array}$ \\
\hline Female sex, $n$ & 74 & 74 & 68 & 23 & 10 \\
\hline Median age, years (range) & $43(21-79)$ & $43(21-79)$ & $42(21-79)$ & $50(28-98)$ & $72.5(46-98)$ \\
\hline Hospitalized, $n$ & 2 & 2 & 2 & 47 & 19 \\
\hline Pneumonia, $n$ & 12 & 12 & 12 & 48 & 20 \\
\hline $\begin{array}{l}\text { Median time between onset of symptoms until serum } \\
\text { sample collection, days (range) }\end{array}$ & $5(1-24)$ & $5(1-24)$ & $5(1-21)$ & $11(3-18)$ & $11(5-18)$ \\
\hline $\begin{array}{l}\text { Median time between serum and nasopharyngeal } \\
\text { aspirate sample collections, days (range) }\end{array}$ & $0(0-17)$ & $0(0-17)$ & $0(0-7)$ & $4(0-13)$ & $5(2-9)$ \\
\hline Positive RT-qPCR patients, $n$ & 55 & 55 & 49 & 46 & 18 \\
\hline Negative RT-qPCR patients, $n$ & 40 & 40 & 40 & 4 & 4 \\
\hline
\end{tabular}

RT-qPCR tests presented a high specificity with a low probability of false positive; however, sensitivity relies on different factors as specimen site, method of collection, viral load and time from the onset of symptoms [3, 7]. An increasing number of cases with negative RT-qPCR and clinical features consistent with COVID-19 pneumonia has been reported [8-10].Therefore, supplementary diagnostic approaches are needed to reduce the number of false-negative cases, which is essential for the epidemiologic control of the disease [11].

Several studies focused on antibody response against SARS-CoV-2 suggested that IgM can be detected during the first week since the onset of the symptoms, although the IgM detection rate is highly variable at this early stage [12-14]. IgG can be detectable after 8 days since the onset of the symptoms, and after 14 days, over $90 \%$ of cases present antibodies against SARS-CoV-2 [13-15]. However, the strength of antibody response depends on several factors (nutritional state, severity of disease, immune status...) and it has been observed that some patients do not produce detectable levels of antibodies $[13,15,16]$.

Therefore, serological methods had limited utility for early diagnosis of COVID-19, since the sensitivity of the assay is low during the first days and increases with time. However, serologic tests could play an important role in confirmation and late diagnostic of COVID-19, mainly in patients with repetitive negative RT-qPCR, as well as giving information about the immune status of asymptomatic patients and contributing to the determination of the prevalence and mortality rate [17]. Combination of RT-qPCR and IgM/IgG detection methods could provide a suitable approach to COVID-19 diagnosis [18].

Several studies suggested that acquired immunity is protective against SARS-CoV2 re-infection [19, 20], though some reports described cases of post-recovery positive nasopharyngeal RTqPCR [21-23]. Currently, is being discussed if the recurrence of positive SARS-CoV-2 RT-qPCR in recovered patients with subsequent negative RT-qPCR is due to prolonged viral shedding with false negative results of RT-qPCR, or a possible re- infection $[21,24,25]$. In this context, the use of serologic test for the follow-up of the immune response in those cases may be useful to a better understanding of the acquired immunity and the possibility of re-infection.

Lateral flow immunoassays (LFIA) for rapid detection of specific antibodies (IgM and IgG) against SARS-CoV-2 in different human specimens (whole blood, serum and plasma) have been developed in response to the pandemic $[18,26]$. This technique is quick and simple to perform and does not require special equipment. In addition, some studies have shown good concordance between the results obtained using whole blood samples (fingerstick blood) and serum or plasma samples so can be used as point-of-care (POC) immunodiagnostic tests, which makes it suitable for community surveillance $[18,26]$. The use of these POC immunodiagnostic tests for massive detection of antibody response to SARS-Cov-2 in the population would be an important step towards a better understanding of the outbreak's situation, which would help us to establish the right policies in the control of the COVID19 pandemic [27]. However, the utility of these LFIA assays is questionable due to the lack of official performance validation to evaluate the sensitivity and specificity of the tests, which are highly variable between the different commercially available serologic tests $[15,28]$.Therefore, further studies are needed to assess the sensitivity and specificity of the serologic test launched to the international market.

The aim of this study is to evaluate three immunocromathographic assays for IgM and IgG detection of COVID-19 in serum samples.

\section{Material and methods}

\section{Immunochromathographic strip assay}

Three different immunochromathographic (ICT) assays for qualitative detection of $\mathrm{IgG}$ and $\mathrm{IgM}$ antibodies against 
SARS-CoV-2 were performed in accordance with the manufacturer's protocols for each device. The kits evaluated were as follows:

- Wondfo®, SARS-CoV-2 Antibody Test (Lateral flow method). (Luogang District, Guangzhou, China).

- $\quad$ T\&D Diagnostics, Sienna®, 2019-nCoV IgG/IgM Rapid Test Cassette (Halifax, Nova Scotia, Canada).

- Prometheus ${ }^{\circledR}$ Bio Inc., 2019-nCoV IgG/IgM Test Cassette (Zhejiang, China).

In summary, for the three of them, $10 \mu$ of serum and 2 drops of buffer solution were added to the corresponding loading area in the cassettes. After a short time (no longer than $20 \mathrm{~min}$ ), the interpretation of the results was done by two observers, based on the appearance of a coloured band. According to manufacturer's instructions, the appearance of a blurred band was considered as a positive result (weak positives).

Sienna ${ }^{\circledR}$ and Prometheus ${ }^{\circledR}$ kits show IgM and IgG bands separately, while Wondfo® detected total antibodies in one band.

\section{RT-qPCR}

Nasopharyngeal swabs were collected, and RNA was extracted using an automated system and analysed using selected RT-qPCR commercial kits routinely used for diagnosis of COVID-19, which are addressed to detect the common targets of SARS-CoV-2: nucleocapside $(\mathrm{N})$, spike (S), envelope (E), Orflab and RdRp genes.

RT-qPCR has been considered the reference for the evaluation of the ICT strip assays.

\section{Samples and patients}

Serum samples were collected between the 8th of March and the 2nd of April at Hospital Universitario La Paz (Madrid, Spain), and were centrifuged at $3000 \mathrm{rpm}$ during $10 \mathrm{~min}$.

The evaluation was performed in two groups of patients. The first group was integrated by 95 healthcare workers at Hospital Universitario La Paz, who attended the occupational health consultation for the first time between the 24th March and the 2nd of April referring symptoms compatible with COVID-19. The second group included 50 patients randomly selected who were admitted to the Emergency Department of the Hospital with positive RT-qPCR or high clinical suspicion of COVID-19. In the first group of patients, serum samples and nasopharyngeal swabs were collected at the same time in 82 patients, while in the other 13 patients, the average time since the nasopharyngeal swab collection and the serum extraction was 7.5 days. Regarding the 
Table 3 Detection of IgM, IgG and IgM/IgG antibodies against SARS-CoV-2 with the three ICT strip assays in positive and negative RT-PCR patients along three periods of time since the onset of symptoms

\begin{tabular}{|c|c|c|c|c|c|c|c|c|c|c|c|}
\hline & & & \multicolumn{9}{|l|}{ PCR } \\
\hline & & & \multicolumn{3}{|c|}{ Early stage } & \multicolumn{3}{|c|}{ Intermediate stage } & \multicolumn{3}{|c|}{ Late stage } \\
\hline & & & Positive & Negative & Total & Positive & Negative & Total & Positive & Negative & Total \\
\hline \multirow[t]{9}{*}{ Sienna ${ }^{\circledR}(n=142)$} & \multirow[t]{3}{*}{$\operatorname{IgM}$} & Positive & 13 & 4 & 17 & 33 & 2 & 35 & 8 & 3 & 11 \\
\hline & & Negative & 28 & 22 & 50 & 15 & 7 & 22 & 1 & 6 & 7 \\
\hline & & Total & 41 & 26 & 67 & 48 & 9 & 57 & 9 & 9 & 18 \\
\hline & \multirow[t]{3}{*}{$\operatorname{IgG}$} & Positive & 11 & 1 & 12 & 33 & 4 & 37 & 7 & 2 & 9 \\
\hline & & Negative & 30 & 25 & 55 & 15 & 5 & 20 & 2 & 7 & 9 \\
\hline & & Total & 41 & 26 & 67 & 48 & 9 & 57 & 9 & 9 & 18 \\
\hline & \multirow[t]{3}{*}{$\operatorname{IgM} / \operatorname{IgG}$} & Positive & 15 & 4 & 19 & 39 & 4 & 43 & 9 & 3 & 12 \\
\hline & & Negative & 26 & 22 & 48 & 9 & 5 & 14 & 0 & 6 & 6 \\
\hline & & Total & 41 & 26 & 67 & 48 & 9 & 57 & 9 & 9 & 18 \\
\hline \multirow[t]{3}{*}{ Wondfo $®(n=114)$} & \multirow[t]{3}{*}{$\mathrm{IgM} / \operatorname{IgG}$} & Positive & 7 & 3 & 10 & 20 & 4 & 24 & 5 & 1 & 6 \\
\hline & & Negative & 30 & 23 & 53 & 7 & 5 & 12 & 1 & 8 & 9 \\
\hline & & Total & 37 & 26 & 63 & 27 & 9 & 36 & 6 & 9 & 15 \\
\hline \multirow[t]{9}{*}{ Prometheus $®(n=88)$} & \multirow[t]{3}{*}{$\operatorname{IgM}$} & Positive & 20 & 22 & 42 & 10 & 5 & 15 & 2 & 6 & 8 \\
\hline & & Negative & 15 & 3 & 18 & 1 & 2 & 3 & 0 & 2 & 2 \\
\hline & & Total & 35 & 25 & 60 & 11 & 7 & 18 & 2 & 8 & 10 \\
\hline & \multirow[t]{3}{*}{ IgG } & Positive & 14 & 10 & 24 & 7 & 4 & 11 & 1 & 2 & 3 \\
\hline & & Negative & 21 & 15 & 36 & 4 & 3 & 7 & 1 & 6 & 7 \\
\hline & & Total & 35 & 25 & 60 & 11 & 7 & 18 & 2 & 8 & 10 \\
\hline & \multirow[t]{3}{*}{ IgM/IgG } & Positive & 24 & 23 & 47 & 10 & 6 & 16 & 2 & 6 & 8 \\
\hline & & Negative & 11 & 2 & 13 & 1 & 1 & 2 & 0 & 2 & 2 \\
\hline & & Total & 35 & 25 & 60 & 11 & 7 & 18 & 2 & 8 & 10 \\
\hline
\end{tabular}

second group, in 48 patients, serum samples were taken days after the swab collection in an average time of 4.3 days, while in two patients, both samples were collected at the same time.

In addition, 20 extra serum samples of randomly selected patients from 2018 were tested as negative control with Prometheus ${ }^{\circledR}$ and Sienna ${ }^{\circledR}$ test. Unfortunately, it was not possible to carry out this evaluation with Wondfo® test due to lack of reagents.

\section{Statistical analysis}

The statistical analysis was performed overall and divided in three different stages according to the time since the symptoms onset: early stage (first week), intermediate stage (second week) and late stage (third week).

The statistical test parameters were calculated according to their definitions, with additional plots generated using GraphPad Prism (version 8). The results from the negative controls were excluded from the overall statistical analysis.

\section{Results}

A total of 145 serum samples from 145 patients were collected: 89 samples, which belonged to the group of healthcare workers, were tested with the three ICT assays, 28 samples ( 6 from the first and 22 from the second group of patients) were tested with Sienna ${ }^{\circledR}$ and Wondfo ${ }^{\circledR}$ and the other 28 samples from the second group of patients were tested only with Sienna. Therefore, 145 samples were tested with Sienna ${ }^{\circledR}, 117$ with Wondfo $®$ and 89 with Prometheus ${ }^{\circledR}$.

Demographic and clinical characteristics of the patients included in the study are collected in Table 1.

The overall results of sensitivity, specificity, positive predictive value (PPV) and negative predictive value (NPV) obtained were as follows: $64.4 \%, 75 \%, 85.5 \%$ and $47.8 \%$ with Sienna ${ }^{\circledR} ; 45.2 \%, 81.8 \%, 80.5 \%$ and $47.4 \%$ with Wondfo ${ }^{\circledR}$ and $75.5 \%, 12.5 \%, 51.4 \%$ and $29.4 \%$ with Prometheus ${ }^{\circledR}$. The accuracy of the test was $67.6 \%$ with Sienna ${ }^{\circledR}, 59 \%$ with Wondfo ${ }^{\circledR}$ and $47.2 \%$ with Prometheus ${ }^{\circledR}$, with a prevalence of COVID-19 of $69.7 \%, 62.4 \%$ and $55.1 \%$ respectively (Table 2). The results of prevalence, accuracy, sensitivity, specificity, PPV 


\section{Sienna IgM}
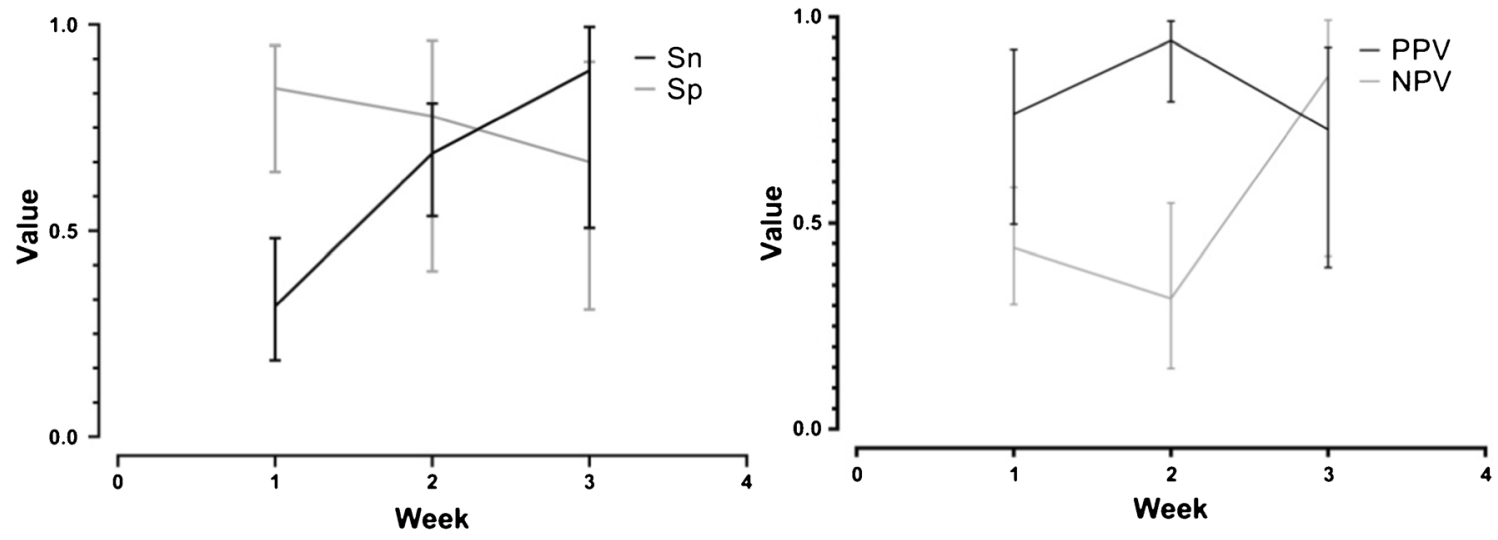

Sienna $\lg \mathbf{G}$
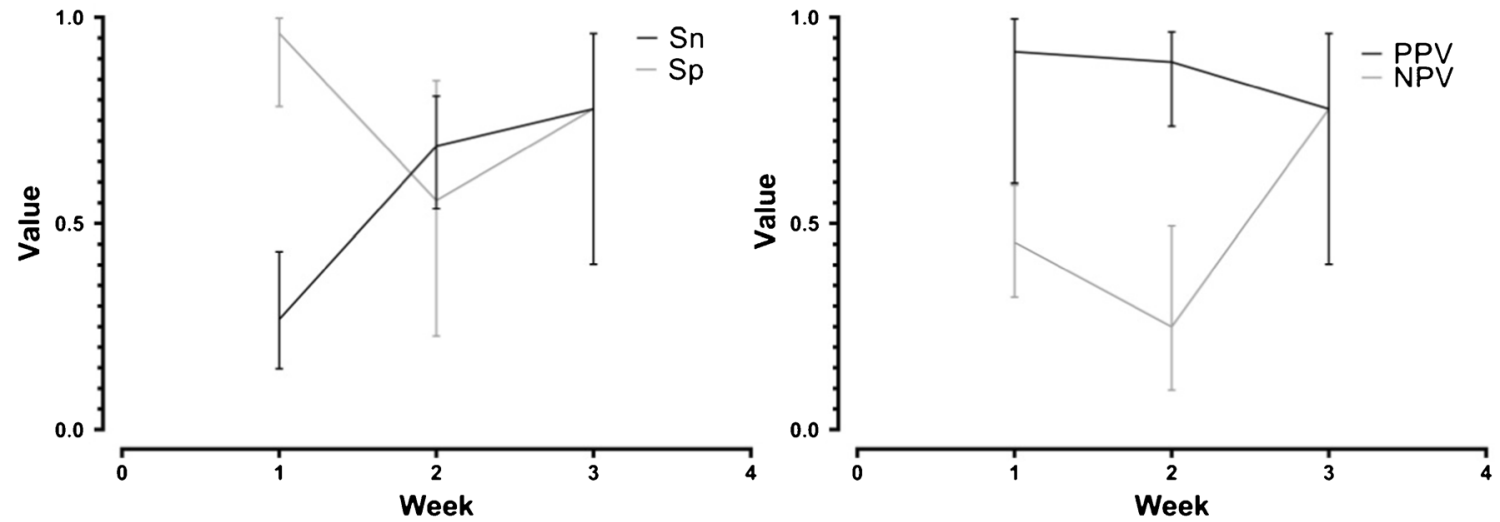

\section{Sienna $\lg M+\lg G$}
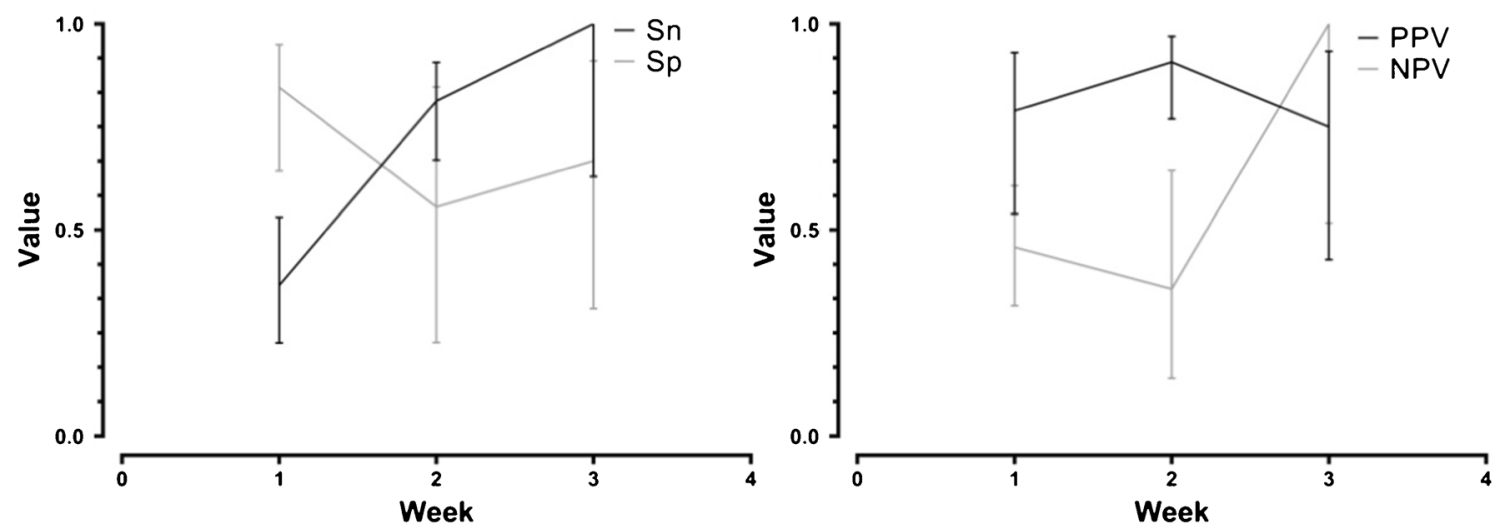

Fig. 1 Diagnostic test parameters of Sienna ${ }^{\circledR}$ broken down into early, intermediate and late stage

and NPV of Prometheus ${ }^{\circledR}$ and Sienna ${ }^{\circledR}$ for $\operatorname{IgG}$ and $\operatorname{IgM}$ detection separately are also available in Table 2.

Detection rate of $\operatorname{IgM}, \operatorname{IgG}$ and $\mathrm{IgM} / \mathrm{IgG}$ antibodies against SARS-CoV-2 with the three ICT strip assays in positive and negative RT-PCR patients along three periods of time since the onset of symptoms is shown in Table 3 .
When the test was performed in patients with less than 1 week since the symptoms onset, the results obtained with Sienna ${ }^{\circledR}(n=67)$, Wondfo $\AA(n=63)$ and Prometheus $(n=60)$ respectively were as follows: sensitivity $36.6 \%, 18.9 \%$ and $68.8 \%$; specificity $84.6 \%, 88.5 \%$ and $8 \%$; PPV $78.9 \%, 70 \%$ and $51.1 \%$ and NPV $45.8 \%, 43.4 \%$ and $15.4 \%$. 


\section{Prometheus IgM}
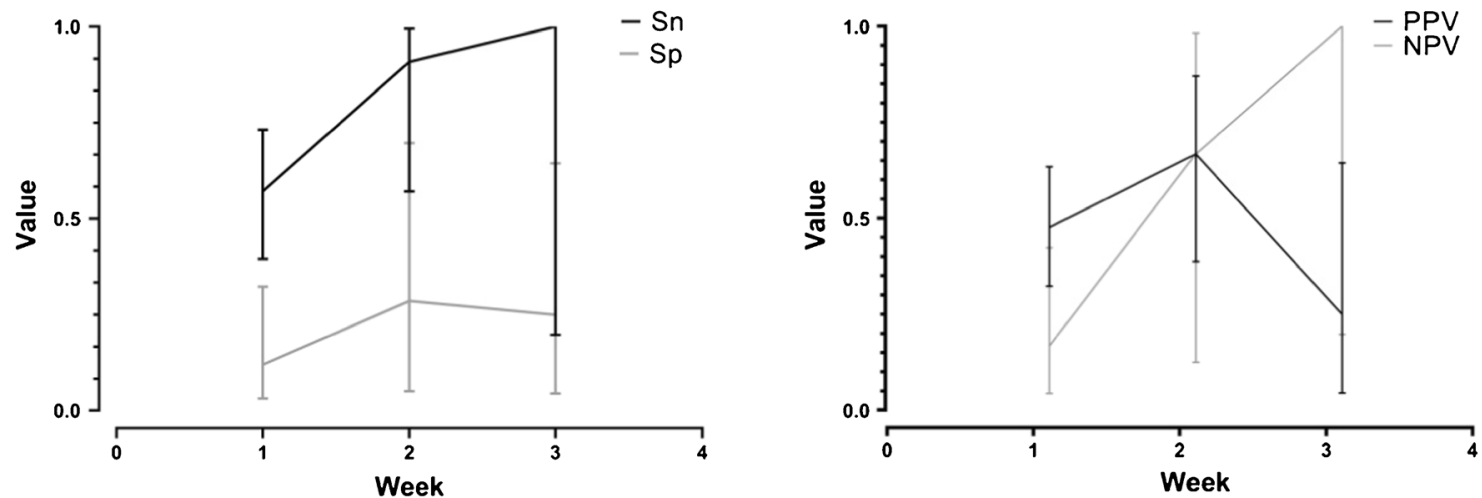

\section{Prometheus IgG}
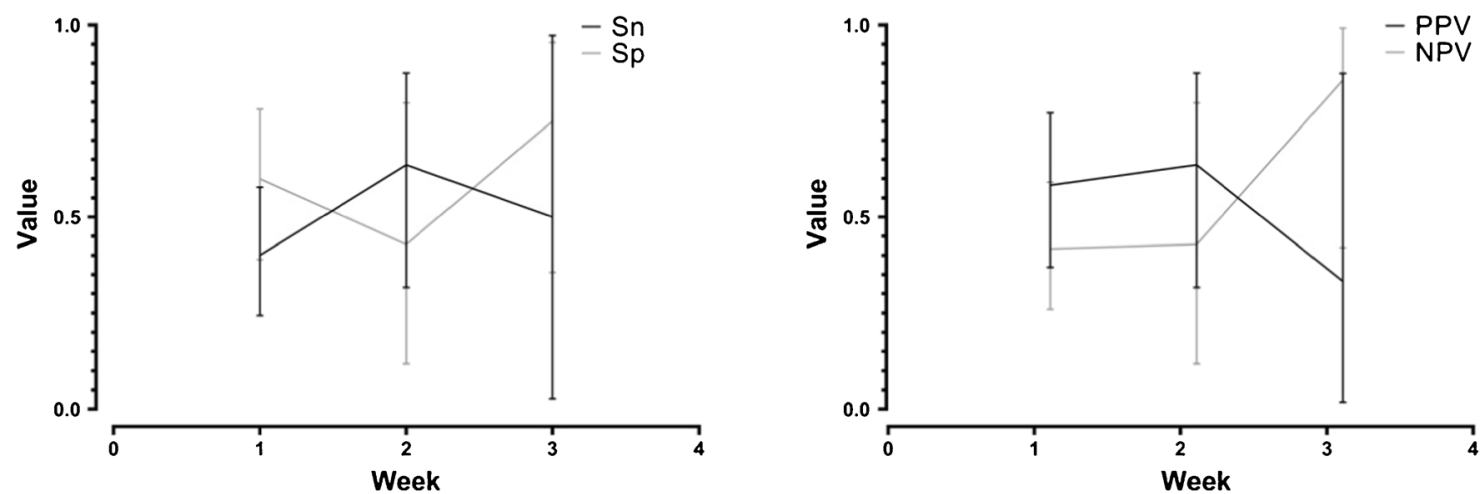

Prometheus $\lg M+\lg G$
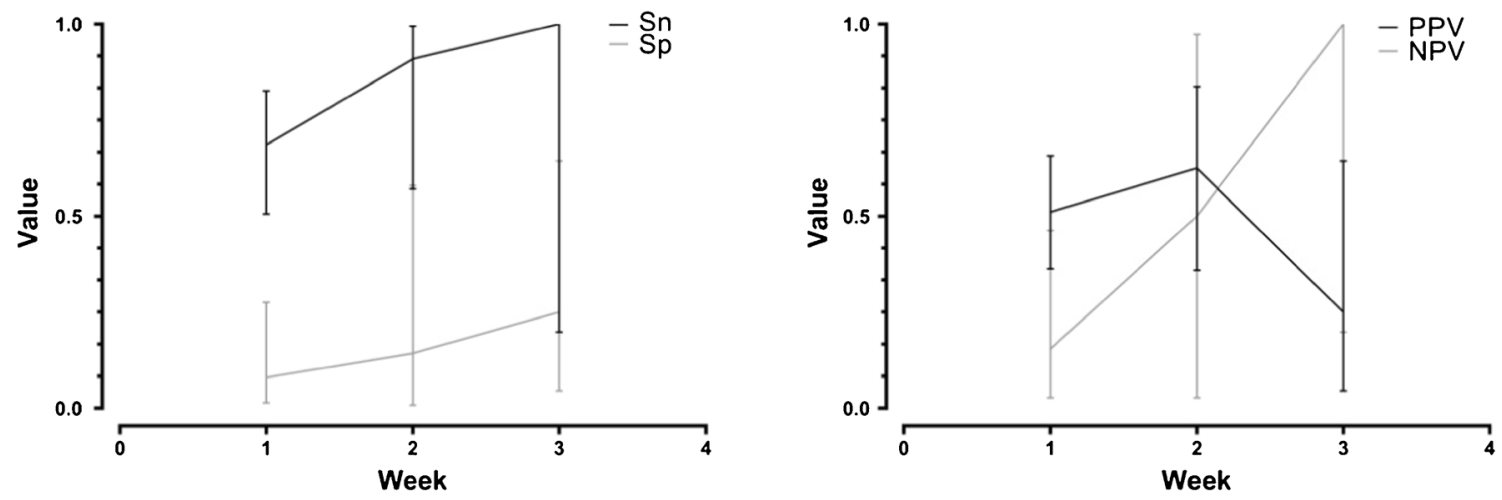

Fig. 2 Diagnostic test parameters of Prometheus ${ }^{\circledR}$ broken down into early, intermediate and late stage

In patients which presented between 7 and 14 days since the onset of symptoms, sensitivity increased to $81.3 \%$ with Sienna ${ }^{\circledR}(n=57), 74.1 \%$ with Wondfo ${ }^{\circledR}(n=36)$ and $90.9 \%$ with Prometheus $(n=18)$. Specificity, PPV and NPV were $55.6 \%, 90.7 \%$ and $35.7 \%$ respectively with Sienna ${ }^{\circledR}$; $55.6 \%, 83.3 \%$ and $41.7 \%$ with Wondfo ${ }^{\circledR}$ and $14.3 \%, 62.5 \%$ and $50 \%$ with Prometheus ${ }^{\circledR}$.
In patients with more than 14 days since the symptoms onset $(n=18)$, sensitivity and NPV reached $100 \%$, with Sienna ${ }^{\circledR}(n=18)$ and Prometheus ${ }^{\circledR}(n=10)$, and $83.3 \%$ and $88.9 \%$ with Wondfo ${ }^{\circledR}(n=15)$. Specificity and PPV were $66.7 \%$ and $75 \%$ with Sienna ${ }^{\circledR}, 88.9 \%$ and $83.3 \%$ with Wondfo ${ }^{\circledR}$ and $25 \%$ and $25 \%$ with Prometheus ${ }^{\circledR}$. 


\section{Wondfo}
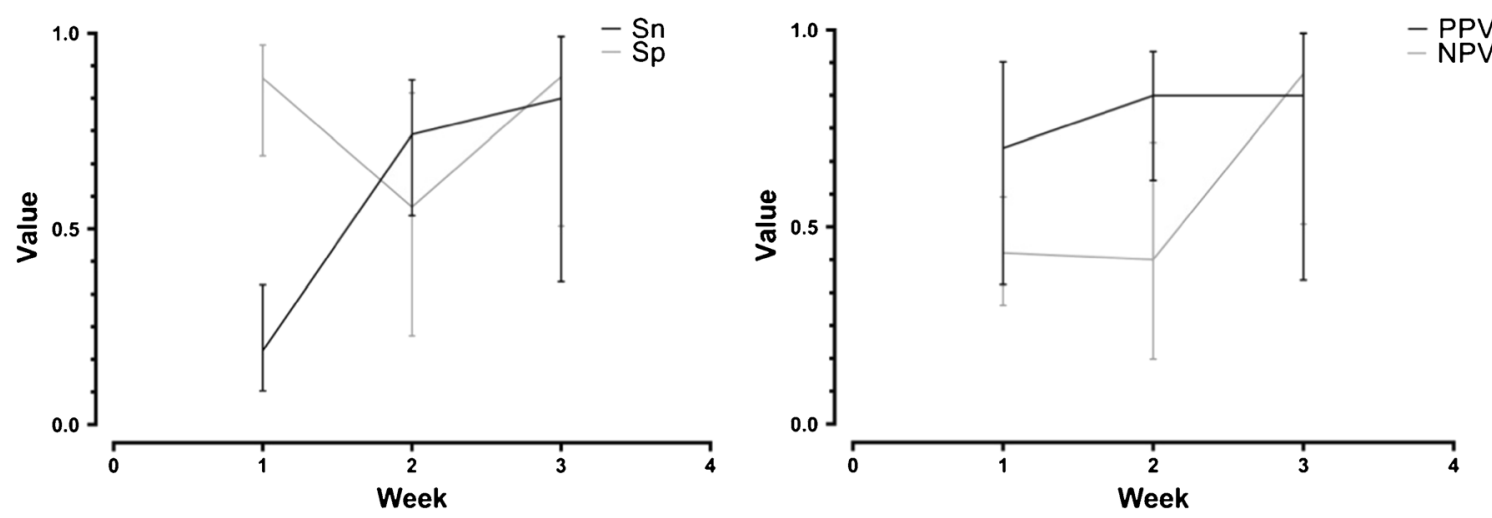

Fig. 3 Diagnostic test parameters of Wondfo® broken down into early, intermediate and late stage

These results of the variation of the test parameters along the three different periods, including $\operatorname{IgG}$ and $\operatorname{IgM}$ detection separately, are available in supplementary material (Table 1).

Antibody detection rate based on the number of days after onset of symptoms of the three ICT assays is determined and summarized in Figs. 1, 2, and 3.

Detection rates of total antibodies (IgM/IgG) obtained with Sienna ${ }^{\circledR}$ and Wondfo ${ }^{\circledR}$ by the two groups of patients along the three stages since the symptoms onset are collected in Table 4.

The calculation of the different test parameters among the three stages was performed excluding three patients because the time since the onset of symptoms was unknown. The three of them were included in the global evaluation of Sienna ${ }^{\circledR}$ and Wondfo ${ }^{\circledR}$ and one was included in the evaluation of Prometheus ${ }^{\circledR}$.

The 20 serum samples from 2018 included as negative control of Sienna ${ }^{\circledR}$ and Prometheus ${ }^{\circledR}$ resulted in one positive sample with an IgM band using Sienna ${ }^{\circledR}$ while seven were positive (2 $\operatorname{IgG}$ and $\operatorname{IgM}, 3 \mathrm{IgG}$ and $2 \mathrm{IgM}$ ) with Prometheus ${ }^{\circledR}$.

\section{Discussion}

Diagnosis of SARS-CoV-2 remains challenging in most fields. First, COVID-19 patients present a range of unspecific clinical symptoms that are similar to those produced by common respiratory tract pathogens. Second, laboratory diagnosis is currently based on RT-qPCR detection of viral RNA from nasopharyngeal samples, which has limitations of sensitivity, especially in later stages of the disease. Therefore, it is essential to optimize laboratory diagnosis, including serological tests as a complementary technique of RT-qPCR for SARSCoV-2 diagnosis.

In this study, we have investigated the diagnostic value of detection of SARS-CoV-2 IgM and IgG antibodies in different stages of the disease, using three ICT strip assays, in comparison with RT-qPCR.

It has been described that during the course of the disease, the sensitivity of the RT-qPCR technique tends to decrease in nasopharyngeal samples, due to a reduction of viral load in this location, while antibodies production raise and serological techniques show a remarkable increase of the sensibility [29] .

We found that the most sensitive test was Prometheus ${ }^{\circledR}$, whose sensitivity was significantly higher during the second and third week of the disease. Sienna ${ }^{\circledR}$ and Wondfo ${ }^{\circledR}$ presented a slightly lower sensitivity which also increased following the same pattern through the evolution of the disease. During the early stages of the disease (first week), the antibody detection rate with the three LFIA test was low, as it has been observed in different published studies [13, 14, 26, 30].
Table 4 Detection rates of total antibodies (IgM/IgG) with Sienna ${ }^{\circledR}$ and Wondfo ${ }^{\circledR}$ in the two groups of patients among the three different stages

\begin{tabular}{|c|c|c|c|c|}
\hline & \multicolumn{2}{|l|}{ Healthcare workers } & \multicolumn{2}{|c|}{$\begin{array}{l}\text { Patients admitted to the Emergency } \\
\text { Department }\end{array}$} \\
\hline & $\begin{array}{l}\text { Sienna® }(n=93) \\
\operatorname{IgM} / \operatorname{IgG}\end{array}$ & $\begin{array}{l}\text { Wondfo® }(n=93) \\
\text { IgM/IgG }\end{array}$ & $\begin{array}{l}\text { Sienna }{ }^{\circledR}(n=49) \\
\operatorname{IgM} / \operatorname{IgG}\end{array}$ & 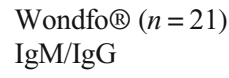 \\
\hline Early stage & $14 / 61(22.9 \%)$ & $8 / 61(13.1 \%)$ & $5 / 6(83.3 \%)$ & $2 / 2(100 \%)$ \\
\hline Intermediate stage & $10 / 18(55.5 \%)$ & $10 / 18(55.5 \%)$ & $33 / 39(84.6 \%)$ & $15 / 18(83.3 \%)$ \\
\hline Late stage & $8 / 14(57.1 \%)$ & $5 / 14(35.7 \%)$ & $4 / 4(100 \%)$ & $1 / 1(100 \%)$ \\
\hline Total & $32 / 93(34.4 \%)$ & $23 / 93(24.7 \%)$ & $42 / 49(85.7 \%)$ & $18 / 21(85.7 \%)$ \\
\hline
\end{tabular}


With Prometheus ${ }^{\circledR}$ and Sienna ${ }^{\circledR}, \operatorname{IgM}$ positive rate was higher than IgG throughout the 3 weeks. However, we have observed that IgM presented a higher number of false positives, especially in the case of Prometheus test. The most specific test was Wondfo $\AA$, followed by Sienna ${ }^{\circledR}$ and last Prometheus®. Both last showed higher specificity in $\operatorname{IgG}$ detection.

Considering the high rate of false positives when using Prometheus ${ }^{\circledR}$ test, an extra 20 serum samples of randomly selected patients from 2018 were studied as negative controls and the results confirmed a high percentage of false positive with this assay (35\%). The same was performed using Sienna ${ }^{\circledR}$, obtaining a much lower rate of false positives $(5 \%)$. Unfortunately, it was not possible to carry out this evaluation with Wondfoß test due to lack of reagents. This indicated the need of further studies to evaluate the specificity and cross-reactions of serological test using negative controls.

These results demonstrate that even though Prometheus ${ }^{\circledR}$ presented a high sensitivity, the specificity was notably lower than the other two tests. Sienna ${ }^{\circledR}$ showed the greatest contrast between sensitivity and specificity, achieving the best accuracy, followed by Wondfo®.

However, there are several limitations in the present study. The current pandemic situation has led to an interrupted availability of the tests, so it has not been possible to carry out the evaluation uniformly with the three kits in the same number of samples. Moreover, the differences between the two groups of patients included in the study may be a potential bias. On one side, in the group of healthcare workers, probably more aware of disease symptoms than the general population, the time elapsed since the onset of symptoms until the attendance to the occupational consultation was considerably lower than in those patients who attended the Emergency Department, which were in more advanced stages of the disease with higher rates of antibodies production. Furthermore, in most healthcare workers, nasopharyngeal swabs and serum samples were collected at the same time and the time between the onset of symptoms and serum sample collection was lower; hence, the sensitivity of serologic tests is reduced. On the other side, patients included in the second group, who were admitted to the Emergency Department, presented a previous positive RT-qPCR or a high clinical suspicion of COVID-19, and consequently the pre-test probability of antibodies production in this group of patients was higher. Finally, the use of RT-qPCR as reference technique for the evaluation of serological test should be taken with care, since both techniques have different time windows for positivity during the course of the infection and RT-qPCR presented a substantial rate of false negatives. In contrast, the low rate of false positives using RT-qPCR enables a consisting evaluation of the sensitivity of serological tests in COVID-19 patients with positive RT-qPCR.
Our study highlights the importance of performing the serological tests when the time since the onset of symptoms is larger than 1 week, since the sensitivity of the three ICT assays was notably higher during the intermediate and late stages of the disease.

Acknowledgements Members of the SARS-CoV-2 Working Group: María Dolores Montero-Vega, María Pilar Romero, Silvia GarcíaBujalance, Emilio Cendejas-Bueno, Guillermo Ruiz-Carrascoso, Fernando Lázaro-Perona, Iker Falces-Romero, Almudena GutiérrezArroyo, Patricia Girón de Velasco-Sada, Alicia Rico Nieto, Belén Loeches, Mario Ruiz-Bastián, Bartolomé Gómez-Arroyo, Paloma García-Clemente, María Gracia Liras-Hernández, Consuelo GarcíaSánchez, Miguel Sánchez-Castellano, Sol San José-Villar, Ester Tato, Cristina Romero Huertas, Elena Molina Muñoz.

\section{Compliance with ethical standards}

Conflict of interest The authors declare that they have no conflict of interest.

Ethical approval Not applicable

Consent to participate Not applicable

Consent for publication Not applicable

\section{References}

1. Zhu N, Zhang D, Wang W, Li X, Yang B, Song J, Zhao X, Huang B, Shi W, Lu R, Niu P, Zhan F, Ma X, Wang D, Xu W, Wu G, Gao GF, Tan W (2020) A novel coronavirus from patients with pneumonia in China, 2019. N Engl J Med 382:727-733

2. Lu R, Zhao X, Li J, Niu P, Yang B, Wu H, Wang W, Song H, Huang B, Zhu N, Bi Y, Ma X, Zhan F, Wang L, Hu T, Zhou H, Hu Z, Zhou W, Zhao L, Chen J, Meng Y, Wang J, Lin Y, Yuan J, Xie Z, Ma J, Liu WJ, Wang D, Xu W, Holmes EC, Gao GF, Wu G, Chen W, Shi W, Tan W (2020) Genomic characterisation and epidemiology of 2019 novel coronavirus: implications for virus origins and receptor binding. Lancet 395:565-574

3. Corman VM, Landt O, Kaiser M, Molenkamp R, Meijer A, Chu DK, Bleicker T, Brünink S, Schneider J, Schmidt ML, Mulders DG, Haagmans BL, van der Veer B, van den Brink S, Wijsman L, Goderski G, Romette JL, Ellis J, Zambon M, Peiris M, Goossens H, Reusken C, Koopmans MP, Drosten C (2020) Detection of 2019 novel coronavirus (2019-nCoV) by real-time RT-PCR. Euro Surveill 25:1-8

4. Loeffelholz MJ, Tang Y-W (1751) Laboratory diagnosis of emerging human coronavirus infections — the state of the art. Emerg Microbes Infect 2020:1-26

5. Tang Y-W, Schmitz JE, Persing DH, Stratton CW (2020) The laboratory diagnosis of COVID-19 infection: current issues and challenges. J Clin Microbiol:1-22

6. World Health Organization.: World Health Organization (2020) Laboratory testing for coronavirus disease 2019 ( COVID-19 ) in suspected human cases: : interim guidance, 2 March 2020. 2019, (2020)

7. Wikramaratna P, Paton RS, Ghafari M, Kingdom U (2020) Estimating false-negative detection rate of SARS-CoV-2 by RTPCR. 413, 0-13 
8. Ai T, Yang Z, Hou H, Zhan C, Chen C, Lv W, Tao Q, Sun Z, Xia L (2019) Correlation of chest CT and RT-PCR testing in coronavirus disease 2019 (COVID-19) in China: a report of 1014 cases. Radiology 2020:200642

9. Xie X, Zhong Z, Zhao W, Zheng C, Wang F, Liu J (Radiology, 2020) Chest CT for typical 2019-nCoV pneumonia: relationship to negative RT-PCR testing. 2003(43)

10. Zhong B-L, Luo W, Li H-MH, Zhang Q-Q, Liu X-G, Li W-T, Li Y, Yi Li O, Rd G, Lee A, Zhou F, Yu T, Du R, Fan G, Liu Y, Liu Z, Xiang J, Wang Y, Song B, Gu X, Guan L, Wei Y, Li H-MH, Wu X, Xu J, Tu S, Zhang Y, Chen H, Cao B, Remuzzi A, Remuzzi G, Lai CC, Shih TP, Ko WC, Tang HJ, Hsueh PR, كي S, Zhao Y, Xu H, Gao J, Tian Z, Yang X, Prevention CC for DC and, Wu Z, McGoogan JM, Numbers SIN, Heymann DL, Shindo N, Dong E, Du H, Gardner L, Khader Y, Al Nsour M, Al Serouri A, Ikram A, Malik E, Saeed K, Abdalla AM, Belalia A, Assarag B, Baig MA, Almudarra S, Arqoub K, Osman S, Bashier H, Abu-Khader I, Shalabi D, Mirbolouki M, Behzadi MH, Korzaledin M, Qarawi ATA, Ng SJ, Gad A, Mai LN, AL-Ahdal TMA, Sharma A, Huan VT, Vuong NL, Tawfik GM, Hashan MR, Dumre SP, Ghozy S, Shaikhkhalil H, Mahmoud MH, Alhady STM, Nam NH, Islam SMS, Smith C, Lee PNC, Chico M, Cox S, Hirayama K, Huy NT, Bedoya G, Dolinger A, Liu Y, Gayle AA, Wilder-Smith A, Rocklöv J (2020) Sensitivity of chest CT for COVID-19: comparison to RT-PCR. Lancet 395:1-A2

11. Cao G, Wang H, Li C. One nosocomial cluster following with a familial cluster of COVID-19 cases : the potential transmission risk in patients with negative swab tests. 1-15

12. Guo L, Ren L, Yang S, Xiao M, Chang D, Yang F, Cruz S Dela Wang Y, Wu C, Xiao Y, Zhang L (2020) Profiling early humoral response to diagnose novel coronavirus disease ( COVID-19). 1-8

13. Zhao J, Yuan Q, Wang H, Liu W, Liao X, Wang X, Yuan J, Li T, Li J, Qian S, Hong C, Fu Y, Ge S, Liu L, Zhang J, Xia N (2020) Antibody responses to SARS-CoV-2 in patients of novel coronavirus disease 2019

14. Three C, Central G, Public T, Hospital TS, Authors C, Huang A (2020) Antibody responses to SARS-CoV-2 in COVID-19 patients: the perspective application of serological tests in clinical practice

15. Theel ES, Slev P, Wheeler S, Couturier MR, Wong SJ (2020) Kadkhoda: the role of antobody testing for SARS-CoV-2: is there one? 1-15

16. Lin D, Liu L, Zhang M, Hu Y, Yang Q, Guo J (2020) Evaluations of serological test in the diagnosis of 2019 novel coronavirus (SARS-CoV-2) infections during the COVID-19 outbreak

17. Zhang W, Du RH, Li B, Zheng XS, Lou YX, Hu B, Wang YY, Xiao GF, Yan B, Shi ZL, Zhou P (2020) Molecular and serological investigation of 2019-nCoV infected patients: implication of multiple shedding routes. Emerg Microbes Infect 9:386-389
18. Li Z, Yi Y, Luo X, Xiong N, Liu Y, Li S, Sun R, Wang Y, Hu B, Chen W, Zhang Y, Wang J, Huang B, Lin Y, Yang J, Cai W, Wang X, Cheng J, Chen Z, Sun K, Pan W, Zhan Z, Chen L, Ye F (2020) Development and clinical application of a rapid IgM-IgG combined antibody test for SARS-CoV-2 infection diagnosis. J Med Virol 0-1

19. Bao L, Deng W, Gao H, Xiao C, Liu J, Xue J, Lv Q, Liu J, Yu P, Xu Y, Qi F, Qu Y, Li F, Xiang Z, Yu H, Gong S, Liu M, Wang G, Wang S, Song Z, Liu Y, Zhao W, Han L, Liu X, Wei Q, Chuan Q (2020) Lack of reinfection in rhesus macaques infected with SARSCoV-2. bioRxiv. https://doi.org/10.1101/2020.03.13.990226

20. Bao L, Deng W, Gao H, Xiao C, Liu J, Xue J, Liu J, Yu P, Xu Y, Qi F, Qu Y, Li F, Yu H, Gong S, Liu M, Wang G, Wang S, Song Z, Zhao W, Han Y, Zhao L, Liu X, Wei Q, Infectious R, Hospital BA (2020) Reinfection could not occur in SARS-CoV-2 infected rhesus macaques. bioRxiv. https://doi.org/10.1101/2020.03.13.990226

21. Bentivegna E. New IgM seroconversion and positive RT-PCR test after exposure to the virus in recovered COVID-19 patient. J Med Virol 0-1

22. Hoang VT, Dao TL, Gautret P (2020) Recurrence of positive SARS CoV - 2 in patients recovered from COVID - 19. J Med Virol n/a, 1-2

23. Lan L, Xu D, Ye G, Xia C, Wang S, Li Y, Xu H (2020) Positive RT-PCR test results in patients recovered from COVID-19. J Am Med Assoc 323

24. Li Y, Yao L, Li J, Chen L, Song Y, Cai Z, Yang C (2020) Stability issues of RT - PCR testing of SARS - CoV - 2 for hospitalized patients clinically diagnosed with COVID - 19. J Med Virol 1-6

25. Xiao AT, Tong YX, Zhan X (2020) False-negative of RT-PCR and prolonged nucleic acid conversion in COVID-19: rather than recurrence. J Med Virol 0-3

26. Pan Y, Li X, Yang G, Fan J, Tang Y, Zhao J, Long X, Guo S, Zhao Z, Liu Y, Hu H, Xue H, Li Y (2020) Serological immunochromatographic approach in diagnosis with SARS-CoV2 infected COVID-19 patients. medRxiv

27. (2020) Advice on the use of point-of-care immunodiagnostic tests for COVID-19. 14-16

28. Krammer F, Simon V (2020) Serology assays to manage COVID19. 1227: $1-5$

29. Yongchen Z, Shen H, Wang X, Shi X, Li Y, Yan J, Chen Y, Gu B (2020) Different longitudinal patterns of nucleic acid and serology testing results based on disease severity of COVID-19 patients. 1751

30. Jin Y, Wang M, Zuo Z, Fan C, Ye F, Cai Z, Wang Y, Cui H, Pan K, $\mathrm{Xu} A$ (2020) Diagnostic value and dynamic variance of serum antibody in coronavirus disease 2019. Int J Infect Dis. https://doi. org/10.1016/j.jijid.2020.03.065

Publisher's note Springer Nature remains neutral with regard to jurisdictional claims in published maps and institutional affiliations. 